\title{
Quality Evaluation of Preferred Meat Product in Bareilly City
}

\author{
Vandita Mishra ${ }^{1}$, Suman Talukder ${ }^{1 *}$, Sanjod Kumar Mendiratta1, Dwaipayan Bardhan², \\ Rajiv Ranjan Kumar' ${ }^{1}$, Rohit Kumar Jaiswal ${ }^{1}$ and B. Gowtham Prasad ${ }^{1}$ \\ ${ }^{1}$ Division of Livestock Products Technology, ICAR-IVRI, Izatnagar, Bareilly, UP, INDIA \\ ${ }^{2}$ Division of Livestock Economics Statistics and Information Tech., ICAR-IVRI, Izatnagar, Bareilly, INDIA
}

*Corresponding author: S Talukder; E-mail: drttalukder@gmail.com

Received: 27 Feb., 2020

Revised: 03 July, 2020

Accepted: 10 July, 2020

\begin{abstract}
The present study was undertaken to evaluate the existing quality of the most preferred meat product in Bareilly city in Uttar Pradesh. According to survey of 15 road side shops and restaurants in city, chicken and mutton Seekh Kabab was found most preferred RTE meat product, agreed by $66.66 \%$ of the retailer. The Kabab samples were collected aseptically and their quality was evaluated, and found that the protein and fat percentage varied significantly $(\mathrm{P}<0.05)$ among samples and ranged between $11.13-13.12 \%$ and $7.34-9.55 \%$ respectively. The oxidative stability of fat is reflected by TBARS value which was found significantly $(\mathrm{P}<0.05)$ variable among samples, raged between $1.64-2.28 \mathrm{mg}$ malonaldehyde $/ \mathrm{kg}$. The total plate count (TPC) observed ranging between 5.62-6.53 $\log _{10} \mathrm{CFU} / \mathrm{g}$, which were above acceptable standard limits for processed meat products for all the samples. Therefore it could be concluded that, there is need to improve the processing and handling practices involved in Kabab preparation and marketing in Bareilly City to secure public health.

\section{HIGHLIGHTS}

(0 Meat products quality of Bareilly city was evaluated.

( Judgement of market meat products were based on the laboratory quality evaluation.

(0 Outcome will help to design future road map for good quality products development.
\end{abstract}

Keywords: Bareilly City, Seekh Kabab, physico-chemical quality, microbial count

The livestock production plays a significant role in Indian agriculture and economy. It provides food, employment and other contributions to the rural developments. At present India is endowed with total livestock population 535.78 Million with an increase of 4.6\% (DAHD, 2019) and the total meat production reached at 7.7 million tonnes in 2017-18 with the annual growth rate of $3.66 \%$ (BAH \& FS, 2018). Globally livestock sector is highly dynamic and in developing countries like India there is increasing demands of livestock products (Thornton, 2010). Vast majority of the Indian population is with their diverse food habit, local taste preferences, culture, tradition, custom and religion, offers a great market for meat and meat products. In recent years the demand for the quality meat and meat product is steadily increasing with the reason of enhanced meat consumption, changing socio-economic status, growing consciousness about healthy diet, nutritional and health benefit by their consumption. India endowed with large number of traditional meat products and processing practices due to inherent ethnic diversity.

There are varieties of traditional meat products in India, and variation depends up on the local taste, preference and economic status. Some common traditional products which are very much common in most of the part of our country are Tandoori chicken, Sheek Kabab, Shami Kabab, Curry, Meat Kofta, Biryani, trending in market in their

How to cite this article: Mishra, V., Talukder, S., Mendiratta, S.K. Bardhan, D., Kumar, R.R., Jaiswal, R.K. and Prasad, B.G. (2020). Quality evaluation of preferred meat product in Bareilly city. J. Anim. Res., 10(4): 569-574.

Source of Support: None; Conflict of Interest: None 
most convenience forms. The specific flavour and aroma of these products are most attractable features of these products. Kababs are one of the popular conveniences ready to eat meat products and are available in food outlets worldwide. These are usually prepared from lamb and beef, though particular styles of Kabab can be made from meat of other animals like chicken, fish etc. Among the different kababs, Seekh kababs are most popular but the costs of these products are high to be affordable to all the sections of society (Bhat et al., 2013). Bareilly is one of the biggest and populated cities in Uttar Pradesh state. Almost every kind of meat cuisines are available here due to its multi cultural population and among these available products, Kabab is the most preferred by the consumers of Bareilly city. Here in this city variety of Kababs are being prepared using different meat (chicken, mutton, chevon, beef, buffalo meat etc.) in the restaurants, road side eateries, fast food corners, multi star hotels and at social and religious functions, where Kababs are served hot to the consumers. Kabab not only forms an important component of traditional cuisine but has now-a-days taken an important place among fast food items (Sofi et al., 2009). It is a comminuted meat products can be prepared from any of the meat species. About $40 \mathrm{gm}$ of salted, spiced and seasoned chopped meat is pressed on to the skewer (steel/aluminum rod) and spreaded over it until it forms an even layer of about 6-8 inch length around the skewer. Raw Kababs are then cooked by charcoal broiling till doneness for about 3-4 minutes with periodical and constant turning. Charcoal broiling has certain advantages over oven-cooked kababs, which include smoky flavor, better color, more yield, better juiciness and texture (Anjaneyulu et al., 2008). Here the scope was to measure the proximate value which gives the nutritional components and to identify the contamination in a serving of ready to eat $K a b a b$ as per high demand of the product. Consumers, have many expectation from the producers regarding sensory attributes, nutritional aspects, hygiene and food safety, which must be fulfilled by them in order to attain a level of satisfaction by the consumers. It should be considered that they are ever more demanding and more informed, accepting this into an important challenge.

\section{MATERIALS AND METHODS}

The experiment was designed to evaluate the quality attributes of most preferred meat product prepared mainly from chicken, chivon, and buffalo meat etc. in different road side shops and restaurants in different part of the city. The quality parameters were also compared among the Kabab samples. The Kabab were studied for their proximate composition, oxidative changes and microbiological status.

\section{Study site and timing}

A survey was conducted with an aim to identify the most preferred ready to eat meat (RTE) product in Bareilly city of Uttar Pradesh state and to evaluate their quality. For that purpose 15 shops were chosen randomly among the shops, engaged in selling of RTE meat product in the city on the basis of their popularity. During survey the retailers were asked to indicate the most popular and demanded RTE meat product. Out of 15 retailers, $10(66.66 \%)$ retailers revealed that the Seekh Kabab, made both of chicken and mutton are most preferred ready to eat meat product of their shops. A similar finding about the popularity of Seekh Kabab has been shown by Talukder et al. (2020) in cities of North India. The Kabab samples were purchased and collected from the selected shops different road side shops and restaurants which were engaged in selling of convenience/ ready to eat meat products. The survey was carried out between April and May, 2019, in every week days and except Tuesday, time of collection was between 7-10 pm.

\section{Selection of retail outlets}

A random sampling procedure was followed for selection of the RTE meat products shops in the city on the basis of their popularity. The details of the shop attended are presented in Table 1. Sampling covers mostly all famous and crowed corners of the city. Kabab samples were collected from 10 retail outlets, packaged in LPDE pouched in sterile conditions, keeping at refrigerated condition $\left(4 \pm 1^{\circ} \mathrm{C}\right)$ brought to laboratory for further evaluation of parameters.

\section{Source of materials}

Chemicals and ingredients of analytical grades were purchased from standard firms (Merck, SRL). Medias for microbiological studies were purchased from Hi-Media Laboratories Pvt. Ltd., Mumbai. 
Table 1: Kabab samples from ten (10) shops in different parts of the Bareilly city

\begin{tabular}{|c|c|c|c|}
\hline $\begin{array}{l}\text { SI. } \\
\text { No. }\end{array}$ & Shop Name & Locality & Kabab \\
\hline 1 & Street shop & $\begin{array}{l}\text { IVRI Road, } \\
\text { Izatnagar }\end{array}$ & Chevon $K a b a b$ \\
\hline 2 & $\begin{array}{l}\text { Sanjog Da Sanjha } \\
\text { Chullaha }\end{array}$ & Pilibhit Bypass & Chicken $K a b a b$ \\
\hline 3 & Rakabadar Cafe & Selection Point & Chevon $K a b a b$ \\
\hline 4 & $\begin{array}{l}\text { Punjabi Chicken } \\
\text { Kabab shop }\end{array}$ & D.D. Puram & Chevon $K a b a b$ \\
\hline 5 & Sher- e Punjab & Rajendra Nagar & Chicken Kabab \\
\hline 6 & Taj Kabab Corner & Sailani Market & Chevon $K a b a b$ \\
\hline 7 & Street Shop & Sailani Market & Chicken $K a b a b$ \\
\hline 8 & Shahi Mejban & Stadium Road & Chevon $K a b a b$ \\
\hline 9 & Afsar Bhai Kabab & Guljar Road & Chevon $K a b a b$ \\
\hline 10 & $\begin{array}{l}\text { Zayka Chicken Kabab } \\
\text { Corner }\end{array}$ & Prem Nagar & Chicken $K a b a b$ \\
\hline
\end{tabular}

$(n=10)$

\section{Estimation of proximate composition}

The moisture, protein, fat and ash content of Kabab samples were determined by following standard methods described by AOAC (1995).

For moisture estimation, $10 \mathrm{~g}$ of mashed sample was transferred in pre-weighed flat bottom aluminium moisture cup, which was transferred to hot air oven at $\left(105 \pm 1^{\circ} \mathrm{C}\right.$ and kept for 16-18 h. Dried sample was then placed in a desiccator having silica gel as desiccant. After $1 \mathrm{~h}$, the cup containing dried sample was weighed. Moisture content was calculated by applying the following formula:

$$
\text { Moisture }(\%)=\frac{W_{2}-W_{3}}{W_{2}-W_{1}} \times 100
$$

(Where, $\mathrm{W}_{1}$ = weight of empty cup, $\mathrm{W}_{2}=$ weight of cup + fresh sample, $\mathrm{W}_{3}=$ weight of cup + dried sample)

Protein percentage was estimated by taking sample $(2 \mathrm{~g})$ and digested in Micro- Kjeldahl digestion assembly mixing with digestion mixture which acts as catalyst (sodium sulfate/potassium sulfate: copper sulfate $=5: 1$ ) and $40 \mathrm{ml}$ sulfuric acid. Flask was placed in an inclined position and heated gently until frothing ceases, then boiled rapidly until solution became clear. The sample was then cooled and distilled water was added to make the volume up to $250 \mathrm{ml}$. The diluted sample $(10 \mathrm{ml})$ was distilled with 10 $\mathrm{ml}$ of $40 \% \mathrm{NaOH}$ using Micro-Kjeldahl distillation unit. Steam was distilled over $20-25 \mathrm{ml}$ of Tashiros indicator ( $2 \%$, boric acid containing, $1.2 \mathrm{ml}, 0.1 \%$ methyl red +0.6 $\mathrm{ml} 0.2 \%$ bromocresol green in alcohol) for 10-15 minutes. The ammonia trapped in boric acid was determined by titrating with $0.1 \mathrm{~N}$ sulfuric acid. The nitrogen percentage was calculated using the following formula:

Nitrogen $(\%)=$

$$
\frac{(\mathrm{A}-\mathrm{B}) \times 0.0014 \times \text { Total volume made }}{\text { Weight of sample taken } \times \text { Volume of distillate }} \times 100
$$

(Where, $\mathrm{A}=$ Titrated value for sample, $\mathrm{B}=$ Titrated value for blank)

Protein percentage was determined by conversion of nitrogen percentage to protein by using conversion factor (6.25) assuming that all the nitrogen in meat was present as protein i.e. protein percentage $=\mathrm{N} \% \times 6.25$.

Fat content in the sample was extracted in Soxhlet extraction unit. Soxhlet extractor was set with reflux condenser and oil flask which was previously dried and weighed. Meat sample (5 g) was taken into fat free extraction thimble, dried in oven for $6 \mathrm{~h}$ at $60^{\circ} \mathrm{C}$ and placed in Soxhlet extraction apparatus. $150 \mathrm{ml}$ of petroleum ether (BP, $60-80^{\circ} \mathrm{C}$ ) was then poured into extraction flask and condenser was joined and placed on Soxhlet extraction heater in order to boil the solvent gently. Extraction was carried out for $16 \mathrm{~h}$ Fat content was calculated by using the following formula:

$$
\text { Fat }(\%)=\frac{W_{2}-W_{1}}{W_{3}} \times 100
$$

$\left(\mathrm{W}_{1}=\right.$ weight of empty flask, $\mathrm{W}_{2}=$ weight of flask + Fat, $\mathrm{W}_{3}=$ weight of sample taken)

For ash percentage, fresh minced sample (5-10 g) was taken in to a pre-weighed crucible and charred on an electric heater and then transferred to Muffle furnace at $\left(550^{\circ} \mathrm{C}\right)$ for $4-5 \mathrm{~h}$. Ashed sample was transferred to desiccator having silica gel as desiccant. After $1 \mathrm{~h}$, the crucible was weighed. The ash content was calculated by the following formula: 


$$
\operatorname{Ash}(\%)=\frac{W_{2}-W_{1}}{W_{3}} \times 100
$$

$\left(\mathrm{W}_{2}=\right.$ Weight of the crucible + sample before ashing, $\mathrm{W}_{1}=$ Weight of the crucible + sample after ashing, $W_{3}=$ Weight of the sample).

The $\mathrm{pH}$ was measured as per the procedure of Trout et al. (1992), by using a combined glass electrode with a digital pH meter (Elico India L1 127).

TBARS value of Kabab samples was determined by using the distillation method described by Tarladgis et al. (1960). $10 \mathrm{~g}$ of sample was homogenized with $50 \mathrm{ml}$ distilled water using homogenizer for 2 minutes. The slurry was quantitatively transferred to a $500 \mathrm{ml}$ Kjeldahl flask which was then rinsed with $45 \mathrm{ml}$ of distilled water and washings were transferred to the flask to which $5 \mathrm{ml}$ of $6 \mathrm{~N} \mathrm{HCl}$ was added. Few drops of liquid paraffin and glass beads were added to prevent frothing and bumping respectively, during heating. The flask was heated to high temperature and $50 \mathrm{ml}$ distillate was collected in a graduated stopper glass beaker.

The distillate was thoroughly mixed and $5 \mathrm{ml}$ of distillate was pipetted in duplicate into $20 \mathrm{ml}$ glass stopper test tubes. $5 \mathrm{ml}$ of TBA (0.02M 2-thiobarburic acid in $90 \%$ glacial acetic acid) was added to each test tube. The contents were mixed well and immersed in boiling water bath for 30 minutes. A blank consisting of $5 \mathrm{ml}$ of distilled water and $5 \mathrm{ml}$ of TBA reagent was similarly prepared. The tubes were cooled for 10 minutes under tap water and optical density was recorded using spectrophotometer (Model: Beckman DU 640, USA) at $538 \mathrm{~nm}$. The O.D. was multiplied by the factor 7.8 and TBARS value was expressed as mg malonaldehyde/kg of sample.

\section{Microbiological quality evaluation of market products}

Total Plate Count was determined following the methods described by FSSAI (2016). The Kabab samples were opened in laminar flow chamber, sterilized by ultra-violet irradiation. About $10 \mathrm{~g}$ of sample was aseptically weighed and transferred to a sterile mortar containing $90 \mathrm{ml}$ sterile $0.1 \%$ peptone water. The sample was homogenized for 2 minutes using ultraturrax tissue homogenizer (T-25 Germany) under sterile condition to make $10^{-1}$ dilution. Further dilutions were made using sterile $0.1 \%$ peptone water as diluent. To prepare $10^{-2}$ dilution, $1 \mathrm{ml}$ from $10^{-1}$ dilution was mixed with $9 \mathrm{ml}$ of $0.1 \%$ peptone water and so on. Proper mixing in serial dilutions was censured by vortexing the test tubes.

Preparation of sample and serial dilutions were made near flame in a horizontal laminar flow apparatus (Model: YS1-188, Yarco Sales, Pvt. Ltd., New Delhi) observing all possible aseptic conditions. Measured plate count agar (23.5g) (Hi-Media Laboratories Pvt. Ltd., Mumbai) was suspended in $1000 \mathrm{ml}$ of distilled water and boiled to dissolve completely and sterilized by autoclaving at $121^{\circ} \mathrm{C}, 15 \mathrm{lbs}$ pressure for 15 minutes. The final $\mathrm{pH}$ of the media was adjusted to $7.0 \pm 0.2$ at $25^{\circ} \mathrm{C}$. The media was cooled to room temperature. When the temperature of media reached about $45-50^{\circ} \mathrm{C}$, the media was poured into sterile plastic petriplates and the petriplates were left until media solidified. The plates were incubated at $35 \pm 2^{\circ} \mathrm{C}$ for $24 \mathrm{~h}$ for checking the plate sterility. After $24 \mathrm{~h}, 100 \mu \mathrm{l}$ from each dilution was poured into sterile petriplates and spread gently with the help of autoclavable sterile spreader. The plates were incubated at $35 \pm 2^{\circ} \mathrm{C}$ for $48 \mathrm{~h}$. Plates showing 30-300 colonies were counted. The number of colonies was multiplied by the reciprocal of the dilution and expressed as $\log _{10} \mathrm{cfu} / \mathrm{g}$.

\section{Statistical analysis}

All the experiments were conducted in duplicates thrice. The data obtained were pooled and analysis of the suitable statistical parameters will be done by ANOVA, using SPSS statistical software.

\section{RESULTS AND DISCUSSION}

The values of proximate composition of the products varied from shop to shop, the reason behind this might be the variation in formulation and processing/handling practices. It is noteworthy that the preparation of $K a b a b$ appeared somewhat standardized among different commercial retailers due to overlapping results and this fact is mostly due to the origin of the ingredients. Even the variation in the meat species used in formulation also might have caused the variation in proximate composition. The vales of proximate composition and the $\mathrm{pH}$ of the samples are presented in Table 2.

The moisture percentage of 10 samples ranged of between $55.20-59.63 \%$, the mean moisture content found $57.36 \%$. 
Table 2: Proximate composition and $\mathrm{pH}$ of the products $(* \mathrm{Mean} \pm \mathrm{S}$.E.)

\begin{tabular}{llllll}
\hline Shop No. & Moisture & Protein & Fat & Ash & pH \\
\hline 1 & $58.09 \pm 0.21^{\mathrm{B}}$ & $11.25 \pm 0.20^{\mathrm{D}}$ & $8.40 \pm 0.23^{\mathrm{C}}$ & $2.15 \pm 0.12^{\mathrm{B}}$ & $6.14 \pm 0.01^{\mathrm{A}}$ \\
2 & $59.63 \pm 0.33^{\mathrm{A}}$ & $12.45 \pm 0.17^{\mathrm{B}}$ & $9.55 \pm 0.17^{\mathrm{A}}$ & $1.70 \pm 0.13^{\mathrm{D}}$ & $6.11 \pm 0.01^{\mathrm{A}}$ \\
3 & $57.84 \pm 0.24^{\mathrm{B}}$ & $11.56 \pm 0.08^{\mathrm{C}}$ & $7.94 \pm 0.14^{\mathrm{D}}$ & $2.40 \pm 0.12^{\mathrm{B}}$ & $6.14 \pm 0.00^{\mathrm{A}}$ \\
4 & $58.62 \pm 0.33^{\mathrm{B}}$ & $13.12 \pm 0.23^{\mathrm{A}}$ & $7.34 \pm 0.21^{\mathrm{E}}$ & $1.92 \pm 0.23^{\mathrm{C}}$ & $6.02 \pm 0.02$ \\
5 & $56.57 \pm 0.50^{\mathrm{C}}$ & $12.76 \pm 0.22^{\mathrm{B}}$ & $8.50 \pm 0.17^{\mathrm{C}}$ & $2.12 \pm 0.11^{\mathrm{B}}$ & $6.00 \pm 0.00$ \\
6 & $55.85 \pm 0.11^{\mathrm{C}}$ & $11.96 \pm 0.19^{\mathrm{C}}$ & $9.01 \pm 0.19^{\mathrm{B}}$ & $2.79 \pm 0.17^{\mathrm{A}}$ & $6.12 \pm 0.04^{\mathrm{A}}$ \\
7 & $57.45 \pm 0.25^{\mathrm{B}}$ & $12.75 \pm 0.18^{\mathrm{B}}$ & $8.43 \pm 0.12^{\mathrm{C}}$ & $1.71 \pm 0.15^{\mathrm{D}}$ & $6.00 \pm 0.06$ \\
8 & $55.20 \pm 0.14^{\mathrm{C}}$ & $11.13 \pm 0.16^{\mathrm{D}}$ & $7.71 \pm 0.15^{\mathrm{D}}$ & $1.97 \pm 0.26^{\mathrm{C}}$ & $5.98 \pm 0.01$ \\
9 & $56.88 \pm 0.62^{\mathrm{C}}$ & $11.93 \pm 0.40^{\mathrm{C}}$ & $8.98 \pm 0.12^{\mathrm{B}}$ & $2.13 \pm 0.14^{\mathrm{B}}$ & $5.87 \pm 0.00$ \\
10 & $57.47 \pm 0.35^{\mathrm{B}}$ & $11.97 \pm 0.16^{\mathrm{C}}$ & $7.76 \pm 0.03^{\mathrm{D}}$ & $1.95 \pm 0.27^{\mathrm{C}}$ & $6.02 \pm 0.02$ \\
\hline Mean value & $57.36 \pm 0.30$ & $12.08 \pm 0.19$ & $8.36 \pm 0.15$ & $2.08 \pm 0.17$ & $6.04 \pm 0.01$ \\
\hline
\end{tabular}

*Mean \pm S.E. with different superscripts in a column differ significantly $(\mathrm{P}<0.05), \mathrm{n}=10$.

Similar observation was found by Bhat and Pathak (2011); they reported the moisture percentage of oven roasted Seekh Kababs ranged from 56.82 to $58.89 \%$. The protein percentage varied between $11.13-13.12 \%$, the mean value found 12.08. The main source of protein in the samples is meat used in the formulation. The fat percentage found to vary between $7.34-9.55 \%$ and the mean value was $8.36 \%$. In general practice it has been observed that meat processors add animal fat in Seekh Kabab formulation to make the product more flavourful. Similar observation has been reported by Khan (2004) for his ready to eat buffalo meat Kabab.

The ash percentage varied from $1.70-2.79 \%$ and its mean values found 2.08. The $\mathrm{pH}$ of the samples found to be ranged from 5.87-6.14, where as the mean value was determined 6.04 .

The other quality attributes of the samples viz., TBARS values and Microbiological count (Total Plate Count) are presented in Table 3 .

The TBARS, which indicate the fat quality of the samples, varied between 1.64-2.28 $\mathrm{mg}$ malonaldehyde $/ \mathrm{kg}$ of sample. The observed values of TBARS in most of the samples were quiet higher than the acceptance level. The mean values of TBARS numbers during the storage period were higher than the minimum threshold value, i.e., 1-2 mg malonaldehyde/kg meat (Watts 1962). The increased in TBARS values might be attributed to oxidation of fat, similar observation has also been reported by Malav et al. (2015).
Table 3: TBARS value and Microbiological quality of the products $(*$ Mean \pm S.E. $)$

\begin{tabular}{lll}
\hline Shop No. & $\begin{array}{l}\text { TBARS } \\
(\mathrm{mg} \text { malonaldehyde/kg) }\end{array}$ & $\begin{array}{l}\text { TPC } \\
\left(\log _{10} \mathrm{CFU} / \mathrm{g}\right)\end{array}$ \\
\hline 1 & $1.77 \pm 0.12^{\mathrm{B}}$ & $6.28 \pm 0.05^{\mathrm{B}}$ \\
2 & $2.19 \pm 0.13^{\mathrm{A}}$ & $6.45 \pm 0.14^{\mathrm{A}}$ \\
3 & $1.87 \pm 0.02^{\mathrm{B}}$ & $5.71 \pm 0.07^{\mathrm{D}}$ \\
4 & $2.35 \pm 0.13^{\mathrm{A}}$ & $6.30 \pm 0.33^{\mathrm{B}}$ \\
5 & $1.64 \pm 0.04^{\mathrm{C}}$ & $6.41 \pm 0.10^{\mathrm{A}}$ \\
6 & $2.26 \pm 0.08^{\mathrm{A}}$ & $5.62 \pm 0.16^{\mathrm{D}}$ \\
7 & $1.71 \pm 0.02^{\mathrm{B}}$ & $6.53 \pm 0.08^{\mathrm{A}}$ \\
8 & $2.26 \pm 0.06^{\mathrm{A}}$ & $5.89 \pm 0.15^{\mathrm{D}}$ \\
9 & $1.59 \pm 0.02^{\mathrm{C}}$ & $6.18 \pm 0.18^{\mathrm{C}}$ \\
10 & $2.28 \pm 0.06^{\mathrm{A}}$ & $6.19 \pm 0.17^{\mathrm{C}}$ \\
\hline Mean value & $2.01 \pm 0.06$ & $6.15 \pm 0.16$ \\
\hline
\end{tabular}

*Mean \pm S.E. with different superscripts in a column differ significantly $(\mathrm{P}<0.05), \mathrm{n}=10$.

The microbiological quality of the Kabab samples was determined by estimation of Total Plate Count (TPC). In the experiments the TPC was found quite higher than the standard acceptable limits in all the samples, varied range between 5.62-6.53 $\log _{10} \mathrm{CFU} / \mathrm{g}$, the lowest count was observed $5.62 \log _{10} \mathrm{CFU} / \mathrm{g}$ while the standard acceptable FSSAI limit i.e. $10^{4}$ for semi cooked /smoked meat/ meat food product (FSSAI, 2016). The overall microbiological quality which is reflected by TPC evaluation, showed that the Seekh Kabab samples collected from different shops were not prepared hygienically and therefore 
recommendation for improved intervention practices while processing.

\section{CONCLUSION}

Here in the present study the most preferred meat products in Bareilly city has been recognized as Seekh Kabab and their quality evaluation have highlighted the nutritional and hygienic attributes of this most preferred non vegetarian street food. There is an optimum content of protein as well as a considerable high amount of microbial contamination observed in average serving size. Therefore, there is need of adoption of hygienic preparation practices for the product development to make it healthier ready to eat meat product. The consumption of an average portion of this common street food contributes with the fat and energy requirements to consumers and it can be an alternative to one of the two daily meals, although with a moderate frequency of consumption. Therefore, as per the demand and expectation of present health conscious consumer of Bareilly city, the nutritional, microbiological and aesthetic quality of $K a b a b$ should be optimized and improved to assure food safety.

\section{REFERENCES}

Anjaneyulu, A.S.R., Thomas, R., Gadekar, Y.P., Lakshmanan, V. and Mahapatra, C.M. 2008. Indian traditional meat products and their processing, quality, present scenario and future prospects. Indian Food Indus., 27(2): 53.

AOAC. 2002. In: Official methods of analysis. $17^{\text {th }}$ Edn., Association of Official Analytical Chemists, Inc, Arlington, VA.

BAH and FS. 2018. Basic Animal Husbandry and Fisheries Statistics, 2016-17. Department of Animal Husbandry, Dairying and Fisheries. Ministry of Agriculture and Farmers Welfare, GOI.
Bhat, Z.F., Pathak, V. and Fayaz, H. 2013. Effect of refrigerated storage on the quality characteristics of microwave cooked chicken Seekh kababs extended with different non-meat proteins. J. Food Sci. Technol., 50(5): 926-933.

DAHD. 2019. 20 $0^{\text {th }}$ Livestock Census, 2019. Department of Animal Husbandry and Dairying. Ministry of Fisheries, Animal Husbandry and Dairying, Government of India, New Delhi.

FSSAI. 2016. Manual of Methods of Analysis of Foods. Meat and Meat Products \& Fish and Fish Products. Food Safety and Standards Authority of India Ministry of Health and Family Welfare, GOI, New Delhi.

Khan, W.A. 2004. Studies on physico-chemical, microbiological, textural and organoleptic qualities of processed and preserved ready-to-eat buffalo meat products, Ph.D. Thesis, submitted to Aligarh Muslim University, Aligarh (India).

Malav, O.P., Sharma, B.D., Talukder, S., Mendiratta, S.K. and Kumar, R.R. 2015. Quality characteristics and storage stability of restructured chicken meat blocks extended with different combinations of vegetative extenders, J. Food Sci. Technol., 52(1): 391-398.

Tarladgis, B.G., Watts, B.M., Younathan, M.T. and Dugan Jr, L. 1960. A distillation method for the quantitative determination of malonaldehyde in rancid foods. J. Ame. Oil Chem. Soci., 37(1): 44-48.

Talukder, S., Mendiratta, S.K., Kumar, R.R., Soni, A. and Bardhan, D. 2020. Evaluation of meat consumption pattern and meat quality in North Indian cities. J. Anim. Res., 10(3): 01-09.

Thornton, P.K. 2010. Livestock production: recent trends, future prospects. Philosoph. Transac. Royal Soci. B: Biol. Sci., 365: 2853-2867.

Trout, E.S., Hunt, M.C., Johnson, D.E., Claus, J.R., Kastner, C.L., Kropt, D.H. 1992. Characteristics of low fat ground beef containing texture modifying ingredients. J. Food Sci., 57(1): 19-24.

Watts, B.M. 1962. Meat products: Symposium on food lipids and their oxidation. AVI Pub. Co. Inc, Westport, pp. 202. 